\title{
Sistem Monitoring Kinerja Karyawan Berbasis Website Dengan Framework SCRUM Pada Penjualan Software ODOO
}

\author{
Rico Ismail Palandeng ${ }^{1}$, Endang Retnoningsih 2,*
}

* Korespondensi: e-mail: endang.retnoningsih44@gmail.com

\begin{abstract}
1 Sistem Informasi; Universitas Bina Insani; Jl. Raya Siliwangi No 6 Rawa Panjang Bekasi Timur 17114 Indonesia, Telp (021) $82436886 /$ (021) 82436996. Fax (021) 824009 24; e-mail: ricoismaile@gmail.com 2 Teknik Informatika; Institut Bisnis Muhammadiyah; Kampus A: Kavling 17A No. 16 Jalan Sersan Aswan RT 002/009 Margahayu Bekasi Timur, 087784621166; email: endang.retnoningsih44@gmail.com
\end{abstract}

\section{Submitted : 12 Agustus 2021 \\ Revised : 16 September 2021 \\ Accepted : 18 Oktober 2021}

Published : $\mathbf{3 0}$ November 2021

\begin{abstract}
The use of technology in companies can encourage performance and ease in evaluating employee performance. The performance monitoring mechanism that still uses a manual system, usually the HRD section receives the progress of the employee's work based on the recording in a spreadsheet such as excell. An excel file containing job updates for each employee becomes a reference as a monitoring parameter for employee work. This makes the work difficult to monitor so that HRD and Directors can find it difficult to assess employee performance. The development of the selected monitoring system is based on the website. With a website-based system, it can make the monitoring process effective and efficient because each employee can directly enter the work process he does directly into the system, and the HRD department can monitor the completion of employee work in real time, thus the Director can assess employee performance more objectively. and with the system as well as the performance monitoring report produced, it can minimize human errors.
\end{abstract}

Keywords: ODOO, ERP, Monitoring, Performance, SCRUM.

\section{Abstrak}

Penggunaan teknologi pada perusahaan dapat mendorong kinerja dan kemudahan dalam penilaian kinerja karyawan. Mekanisme monitoring kinerja yang masih menggunakan sistem manual, biasanya bagian HRD menerima progres pekerjaan karyawan berdasarkan pencatatan dalam lembar kerja spreed sheet seperti excell. File excel yang berisi update pekerjaan masing-masing karyawan menjadi acuan untuk sebagai parameter monitoring terhadap pekerjaan karyawan. Hal ini menjadikan pekerjaan sulit dimonitoring sehingga HRD dan Direktur dapat kesulitan dalam menilai kinerja karyawan. Pembangunan sistem monitoring yang dipilih bebasis website. Dengan sistem berbasis website dapat membuat proses monitoring menjadi efektif dan efisien karena setiap karyawan dapat secara langsung mengisikan proses pekerjaan yang dilakukannya secara langsung kedalam sistem, dan bagian HRD dapat memonitor penyelesaian pekerjaan karyawan secara real time, dengan demikian Direktur dapat menilai kinerja karyawan secara lebih objektif dan dengan sistem juga laporan monitoring kinerja yang dihasilkan dapat meminimalisir adanya human error.

Kata kunci: ERP, Kinerja, Monitoring, ODOO, SCRUM. 


\section{Pendahuluan}

Produk dan layanan sebaik apapun yang ditawarkan perusahaan kepada kepada klien tidak akan berarti tanpa adanya pemasaran yang baik (Ikhsan et al., 2019). Salah satu cara pemasaran serta penjualan dengan memanfaatkan teknologi seperti fasilitas email dan pelayanan dapat dilakukan layanan berbasis website. ODOO merupakan aplikasi berbasis open source yang menerapkan sistem Enterprise Resource Planning (ERP) dalam mengelola elemen-elemen bisnis dalam perusahaan secara terintegrasi dalam satu aplikasi.

Sumber daya manusia merupakan salah satu asset yang penting oleh karena itu harus dikelolah secara cermat dan sejalan dengan kebutuhan organisasi (Larasati, 2018). Kinerja adalah kinerja adalah tentang prilaku atau apa yang dilakukan oleh karyawan, bukan tentang apa yang diproduksi atau dihasilkan dari pekerjaan mereka (Fattah, 2017). Penilaian karyawan adalah upaya penilaian terhadap kinerja karyawan, secara umum sebagai upaya guna mengadakan pengukuran atas kinerja dari setiap karyawan perusahaan (Budirahardjo, 2015). Faktor-faktor yang dinilai dalam kinerja pegawai seperti efektifitas apabila hasil pekerjaan karyawan mencapai tujuan dan efisien apabila kinerja karyawan memuaskan sesuai harapan pimpinan (Riniwati, 2016). Dengan sistem pencatatan menggunakan spread sheet seperti excell menyebabkan kesulitan mencari data-data yang diperlukan, serta adanya karywan tidak memiliki kemampuan mengolah data menggunakan rumus spread sheet (Dewi \& Andriyani, 2017). Dalam melakukan kegiatan pemantauan kinerja karyawan pada era modern ini ada banyak cara untuk membuat pemantauan menjadi efektif salah satunya adalah monitoring kinerja karyawan berbasis website karena karyawan akan dengan mudah mengupdate hasil pekerjannya setiap saat.

PT Arkana Solusi Digital yang bergerak dalam IT Development khususnya aplikasiaplikasi Enterprise Resource Planning (ERP) menangani berbagai permasalahan kliennya menggunakan software $O D O O$ sebagai solusi menyelesaikan permasalahan bagi perusahaan yang memiliki berbagai elemen bisnis. Sebagai perusahaan yang bergerak dalam bidang IT Development, menjadi hal yang penting untuk melakukan monitoring terhadap tahap perkembangan kinerja karyawannya dalam menyelesaikan setiap pekerjaan dalam memberikan penawaran dan pelayanan penerapan $O D O O$ bagi klien dan mengetahui status progress setiap tahapan dalam menerapkan modul-modul ODOO.

Monitoring memberikan informasi status pengukuran dan evaluasi berulang dari waktu ke waktu, untuk memeriksa terhadap proses atau kemajuan yang sedang berjalan. PT Arkana Solusi Digital, dalam melakukan monitoring kinerja dilakukan oleh HRD dengan meminta report progress pekerjaan ke setiap karyawan. Oleh karena itu diperlukan sebuah sistem untuk dapat mempermudah monitoring pada PT Arkana Solusi Digital. Manfaat penilaian dan monitoring kinerja yang dilakukan dengan objektif, tepat dan secara baik didokumentasikan dapat menurunkan penyimpangan yang berpotensi dilakukan oleh karyawan, sehingga kinerja karyawan diharapkan bertambah baik sesuai dibutuhkan perusahaan (Utomo \& Putra, 2017). 
Monitoring dilakukan oleh bagian Human Resource Development (HRD) dalam hal ini (a) Bagian HRD memonitoring kinerja karyawan dengan cara karyawan memasukan data pekerjaannya kedalam excel sesuai format yang ditentukan oleh bagian HRD; (b) Proses monitoring yang dilakukan oleh HRD membutuhkan waktu lebih lama; (c) Bagian HRD membuat laporan kinerja karyawan menggunakan data yang belum akurat sebagai penilaian kinerja karyawan. Proses monitoring dan penilaian kinerja dengan sistem informasi online dan berbasis website dapat dipercepat karena diakses secara real time, dapat mempermudah pimpinan memperoleh data secara aktual (Wahyuniardi et al., 2015). Sehingga perusahaan dan sistem informasi sebagai kesatuan antara sistem fisik dan sistem sosial dapat mencapai tujuan yang ingin dicapai perusahaan (Tyoso, 2016).

\section{Metode Penelitian}

Pengumpulan data dalam penelitian dilakukan observasi dan wawancara pada PT Arkarna Solusi Digital. Wawancara dilakukan langsung ke PT Arkana Solusi Digital pada bagian HRD terkait persoalan-persoalan yang diteliti untuk mengetahui informasi-informasi yang lebih detail mengenai sistem monitoring kinerja karyawan pada PT Arkana Solusi Digital.

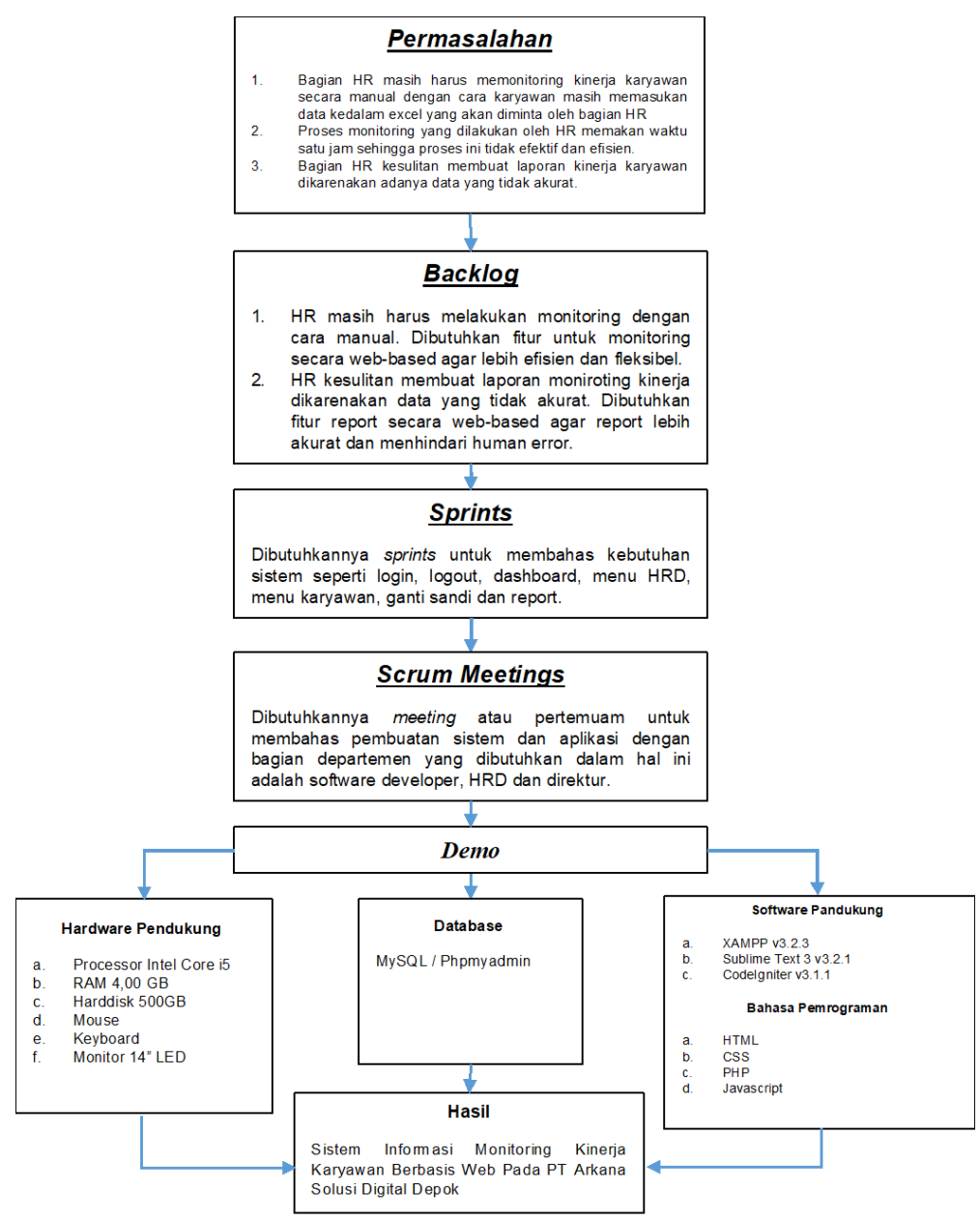

Sumber: Hasil Penelitian (2020)

Gambar 1. Kerangka Pemikiran Penelitian 
Dengan pengumpulan data yang telah dilakukan sehingga dapat diketahui permasalahan yang terjadi dan juga solusi untuk mengatasi permasalahan, sebagaimana tergambar dalam kerangka pemikiran penelitian pada gambar 1. Kebutuhan pembangunan sistem informasi yang cepat diperlukan metode yang sesuai, seperti Agile Software Development. Salah satu yang termasuk sebagai metode Agile adalah framework SCRUM (Salsabila et al., 2019). Berdasarkan kerangka pemikiran, maka dapat diuraikan pembahasan masing-masing tahap dalam penelitian dilakukan sesuai dengan tahapan yang terdapat pada framework SCRUM. Adapun tahapan tersebut dimulai dari tahap Backlog, tahap Sprints, tahap Scrum Meetings, dan tahap Demo (Dewi \& Andriyani, 2017).

Backlog merupakan daftar kebutuhan atau fitur yang memberikan nilai bisnis klien, dan produk backlog yang dibuat dapat bertambah. Sprints adalah unit pekerjaan yang diperlukan untuk memenuhi kebutuhan yang ditetapkan dalam backlog sesuai dengan waktu yang ditetapkan dalam time-box. Selama proses ini berlangsung backlog tidak ada penambahan. Scrum Meetings, aktivitas scrum meetings merupakan pertemuan rutin yang dilakukan untuk mengevaluasi apa yang telah dikerjakan, hambatan yang ada, dan target penyelesaian untuk bahan meeting selanjutnya. Demo menunjukkan progress aplikasi dilakukan untuk memberikan peningkatan perangkat lunak kepada user yang telah diimplementasikan sehingga dapat ditunjukan dan dievaluasi oleh user.

\section{Hasil dan Pembahasan}

Dalam penelitian sistem monitoring kinerja karyawan ini, dilakukan sebagaimana kerangka penelitian. Dimulai dari permasalahan menentukan Backlog, Sprint, Scrum Meeting hingga Demo. Dalam hal ini pengguna dari sistem informasi adalah (a) Bagian HRD (Human Resource Development), merupakan pengguna sistem tertinggi atau mempunyai semua hak akses terhadap sistem ini dimana dia dapat membuat surat dan memonitoring kinerja sales dan juga pekerjaannya HRD itu sendiri; (b) Karyawan bagian Sales, pengguna sistem yang bertanggung jawab untuk me-follow up klien dari Inquiry yang telah diberikan; (c) Direktur dan HRD merupakan pengguna sistem yang dapat mencetak report sales.

\subsection{Proses Bisnis Sistem}

Sales menangani permintaan costumer melalui email, online chat, telepon dengan menanyakan perihal kebutuhan yang diinginkan. Mengelola dan menginput data klien sesuai dengan permintaan kebutuhan melalui dashboard inquiry perusahaan, untuk memunculkan nomor inquiry (nomor surat). Tujuannya adalah untuk melakukan tindak lanjut pelayanan, untuk memberikan feedback kepada customer.

Membuat email terstruktur, membalas email kepada customer setelah membuat nomor inquiry dengan subject (nomor inquiry, kebutuhan, dan nama perusahaan). Isi pesan dalam email berupa konfirmasi dan meyakinkan customer terhadap kebutuhan yang diajukan sebelumya. Apabila customer tidak mencantumkan informasi data perusahaan atau user untuk keperluan database, diberikan format lengkap form database inquiry. 
Koordinasi terhadap permintaan kebutuhan customer kepada bagian research and development untuk dilakukan analisa kebutuhan customer. Jika kebutuhan customer dapat dipenuhi maka Sales akan memperbarui repetisi status pesanan dan rincian pengiriman produk untuk dapat menginformasikan kepada customer, dan mengirimkan surat penawaran (quotation) yang berisikan penawaran harga produk dan proposal teknis yang dikeluarkan oleh PT Arkana Solusi Digital. Didalam quotation terdapat batas waktu surat penawaran, metode pembayaran,syarat dan ketentuan. Penerbitan quotation atau penawaran dilakukan setelah permintaan kebutuhan produk dari customer sudah diperhitungkanoleh divisi financial sesuai dengan penetapan harga dan margin yang ditentukan oleh perusahaan.

Melakukan follow up terhadap customer. Kegiatan follow up menggunakan media email atau telepon, dalam kegiatan ini sebagai tenaga penjual membantu untuk memberikan respon mengenai permintaan kebutuhan calon klien, melakukan kerjasama tim antara divisi Sales, dan melakukan follow up kepada customer. Mengelola dan mempertahankan hubungan dengan customer. Sales diharapkan mampu membangun hubungan dengan cutomer.Setelah terjadinya keputusan pembelian (after sales), pihak sales mampu menciptakan nilai dengan membangun kepercayaan untuk menjalin hubungan jangka panjang. Berikut pada gambar 2 , menunjukkan diagram aktifitas proses bisnis kegiatan yang dilakukan.

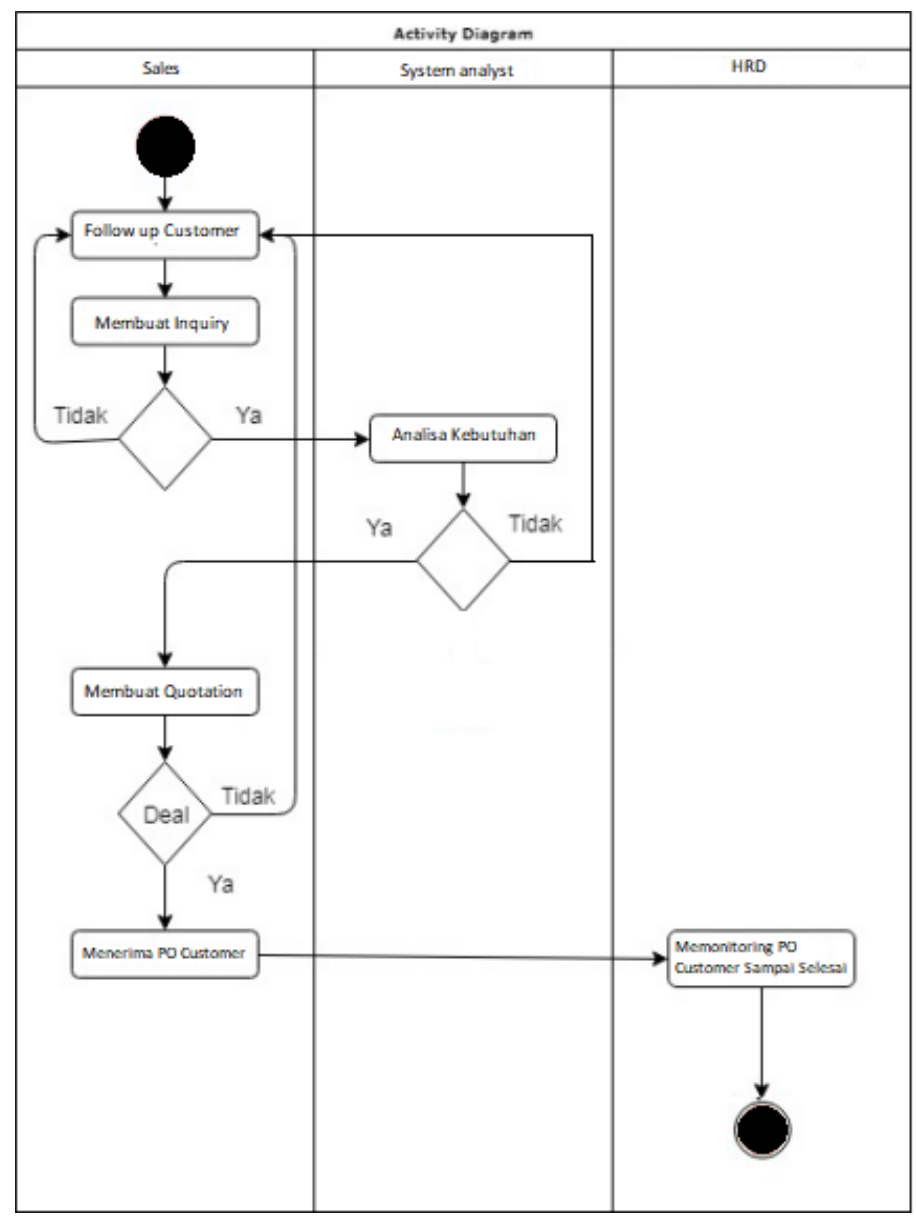

Sumber: Hasil Penelitian (2020)

Gambar 2. Activity Diagram Proses Bisnis 


\subsection{Spesifikasi Dokumen Sistem Berjalan}

Dalam spesifikasi sistem berjalan ini akan dijelaskan mengenai dokumen-dokumen yang terdapat dalam proses pencatatan datanya, dokumen-dokumen tersebut terdiri atas dokumen masukan dan dokumen keluaran. Dokumen masukan berupa (a) Form Inquiry dokumen yang diberikan sales kepada bagian customer untuk melakukan tindak lanjut pelayanan, untuk memberikan feedback kepada klien; (b) PO Customer, dokumen yang diberikan klien kepada PT Arkana Solusi Digital bagian pembelian mengenai barang atau jasa yang akan dibeli. Dokumen masukan berupa (a) Form Quotation, dokumen yang berisikan penawaran harga produk dan proposal teknis yang dikeluarkan oleh PT Arkana Solusi Digital. Didalam quotation terdapat batas waktu surat penawaran, metode pembayaran, syarat dan ketentuan. Dokumen masukan dan keluaran ini menjadi dokumen yang dapat menunjukkan kinerja karyawan dalam mencapai target penjulan software ODOO oleh setiap karyawan.

\subsection{Desain Sistem Monitoring Kinerja Karyawan}

Pada sistem yang dibangun kebutuhan sistem mulai dari Entity Relationship Diagram (ERD), spesifikasi file, use case, struktur navigasi dan website yang dihasilkan. File atau tabel yang terbentuk dari tranformasi $E R D$ seperti tabel inquiry dan tabel detail inquiry menampung seluruh data inquiry, tabel klien menampung seluruh data klien, tabel status menampung seluruh data status, tabel purchasing order dan tabel status purchasing order berisi field-field yang menampung seluruh data purchasing order.

Tabel 1. Spesifikasi Tabel Purchasing Order

\begin{tabular}{|c|c|c|c|c|c|}
\hline No & Elemen Data & Nama Field & Tipe & Size & Ket \\
\hline 1 & Nomor & Nomor & int & 11 & Primary Key \\
\hline 2 & Nomor Urut Inquiry & Nomor_urut_inquiry & char & 4 & Foreign Key \\
\hline 3 & Tanggal Deadline & Tanggal_deadline & date & - & \\
\hline 4 & Kode Kantor Klien & Kode_kantor_klien & char & 6 & Primary Key \\
\hline 5 & Kode Status & Kode_status & char & 2 & Foreign Key \\
\hline 6 & Kode User & Kode_user & char & 6 & Foreign Key \\
\hline 7 & $\begin{array}{l}\text { Update Purchasing } \\
\text { Order }\end{array}$ & Update_purchasing_order & text & - & \\
\hline 8 & $\begin{array}{l}\text { Kode } \\
\text { StatusPurchasing } \\
\text { Order }\end{array}$ & kode_status_purchasing_order & char & 2 & Foreign Key \\
\hline 9 & Nomor PO & Nomor_po & varchar & 255 & \\
\hline 10 & Nilai Quote Inquiry & nilai_quote_inquiry & int & 11 & \\
\hline 11 & Discount & nama klien & int & 11 & \\
\hline 12 & Kode Prog & telepon klien & char & 2 & Foreign Key \\
\hline
\end{tabular}

Use case diagram pada sistem monitoring kinerja karyawan sebagaimana pada gambar 3 bagaimana user berkomunikasi dengan sistem yang dibangun. Aktor sebagai pengguna sistem ini antara lain sales yang merupakan karyawan dalam hal ini yang akan dimonitoring kinerja progress penjualan software ODOO mulai dari pembuatan inquiry, quotation, dan lapora status progress pekerjaannya. HRD melakukan monitoring kinerja setiap karyawan melihat capaian target purchaing order dan menyajikan dalam bentuk laporan kepada Direktur sebagai bentuk monitoring penilaian kinerja karyawan. 


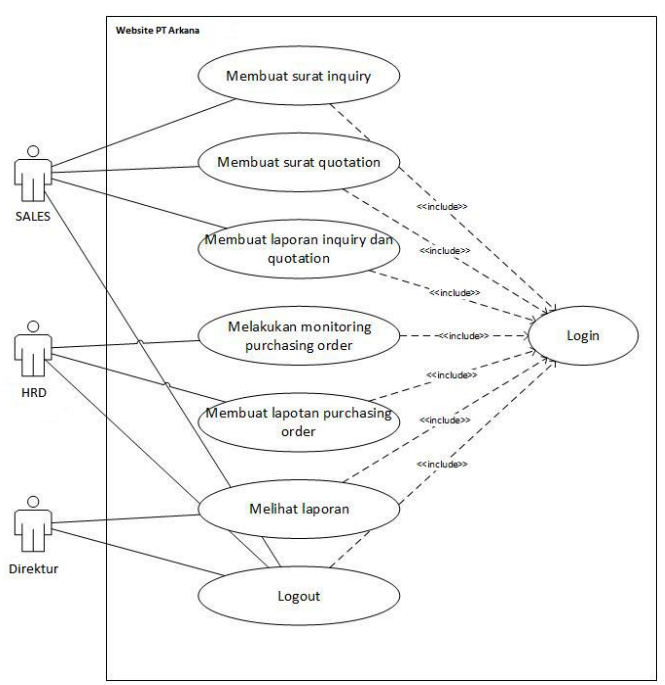

Sumber: Hasil Penelitian (2020)

Gambar 3. Use Case Diagram Sistem Informasi Monitoring Kinerja

\subsection{Monitoring Kinerja Karyawan}

Sesuai langkah-langkah pada kerangka penelitian gambar 1, akan terlihat kinerja dari setiap karyawan sampai dimana progress dari setiap proyek yang ditangani oleh karyawan sehingga memudahkan untuk melakukan monitoring oleh bagian HRD.

\section{Backlog}

Pada tahap ini teridentifikasi kendala pada PT. Arkana yang dimana HRD dalam melihat progres tugas yang sudah diselesaikan oleh karyawan masih dilakukan secara manual sehingga membutuhkan fitur untuk melihat atau monitoring tugas karyawan, berikut adalah daftar fitur yang dibutuhkan: (a) Login, untuk masuk kedalam aplikasi; (b) Logout, untuk keluar dari aplikasi; (c) Dashboard, berisi menu-menu yang dibutuhkan seperti menu karayawan, menu HRD, ganti sandi, backup data untuk admin dan reporting; (d) HRD (Human Resource Development), untuk melihat atau monitoring tugas karyawan; (e) Karyawan, untuk karyawan menginput progress pekerjaannya; (f) Report, untuk melihat laporan penyelesaian pekerjaan dan melakukan export report kedalam file excel.

\section{Sprints}

Pada tahap ini dilakukan meeting untuk menentukan unit pekerjaan yang di butuhkan adalah bagian Software Developer sebagai perancang dan pembuat aplikasi, Karyawan dan HRD sebagai pembantu untuk diberi masukan dan tambahan pada aplikasi yang sesuai dengan kebutuhan.

\section{Scrum Meetings}

Pada tahap ini pertemuan rutin dilakukan oleh tim Software Developer, karyawan dan HRD serta direktur.

\section{Demo}

Berikut ini software yang untuk mendukung demo aplikasi sistem informasi monitoring pendukung seperti XAMPP sebagai web server, MySQL/Phpmyadmin sebagai database, Sublime Text sebagai code editor, Google Chrome sebagai browser untuk mengakses sistem 
dan juga Codelgniter sebagai framework PHP dan Boostrap sebagai framework CSS, lalu HTML digunakan untuk membuat kerangka website dimana kerangka tersebut akan diperindah dengan CSS sehingga tampilan akan lebih terserukur dan rapih serta stunning, PHP sebagai bahasa pemrograman untuk membuat halaman yang dinamis yang didukung oleh JavaScript baik dari sisi front-end tampilan ataupun back-end dari sistem sehingga membuat halaman website lebih mudah dipahamai (user friendly) dan berorientasi pada kenyamanan pengakses (user experience).

\subsection{Tampilan Sistem Informasi Monitoring Kinerja Karyawan}

Form Purchase Order ( $P O$ ) merupakan form dalam sebuah sistem dimana sudah terjadi deal $P O$ dengan klien dan manager HRD mengkontrol $P O$ tersebut sampai selesai, berikut gambar 4 form $\mathrm{PO}$.

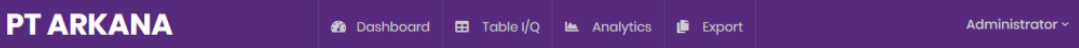

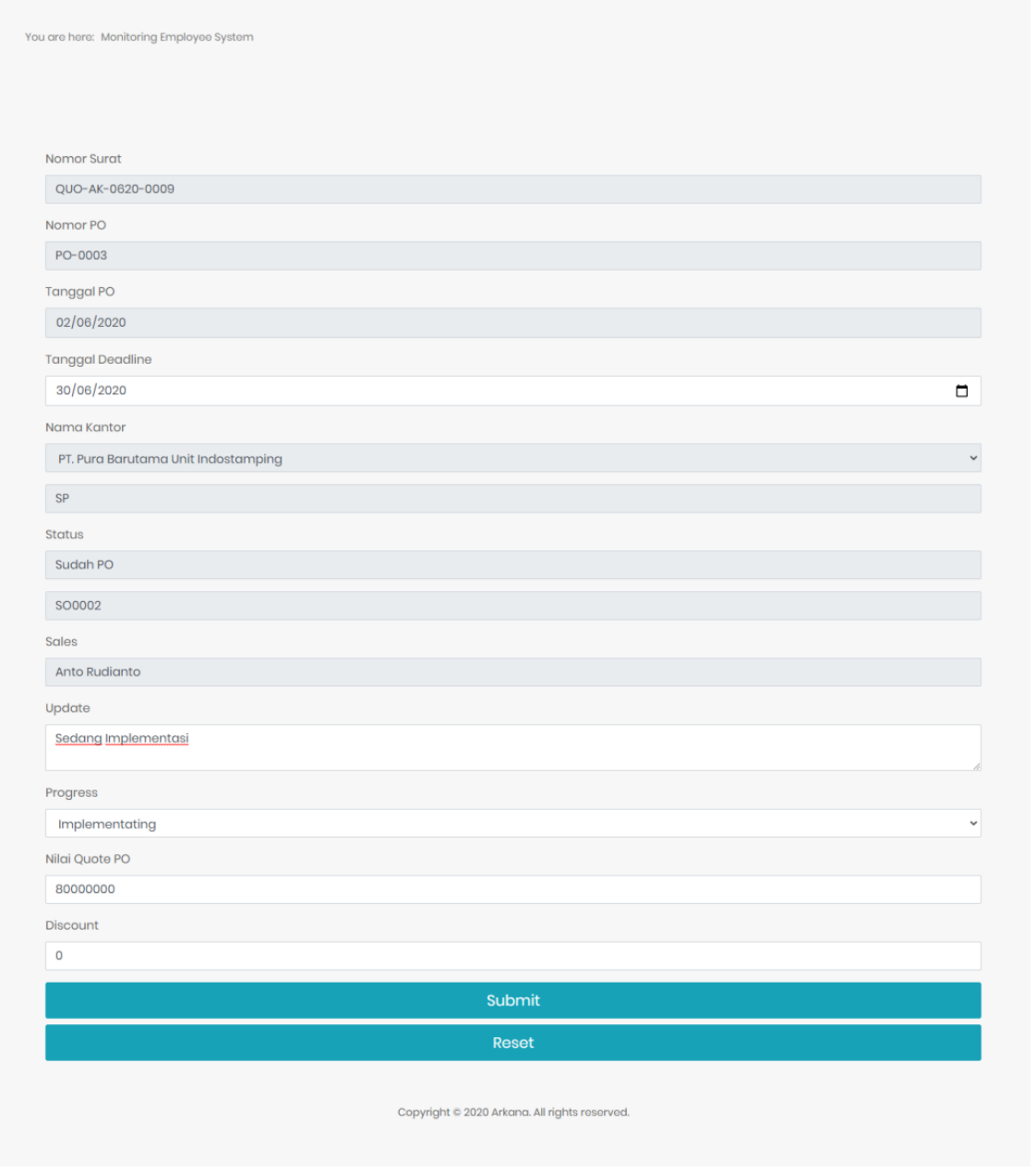

Sumber: Hasil Penelitian (2020)

Gambar 4. Form PO (Purchase Order)

Form Progress merupakan form yang digunakan sales untuk memasukkan progres dari inquiry, Quotation dan Purchase Order dari klien yang ditangani. Sales dapat memasukkan 
kode status dan keterangan status progres pekerjaannya kedalam form ini, berikut adalah gambar 5 form progress.

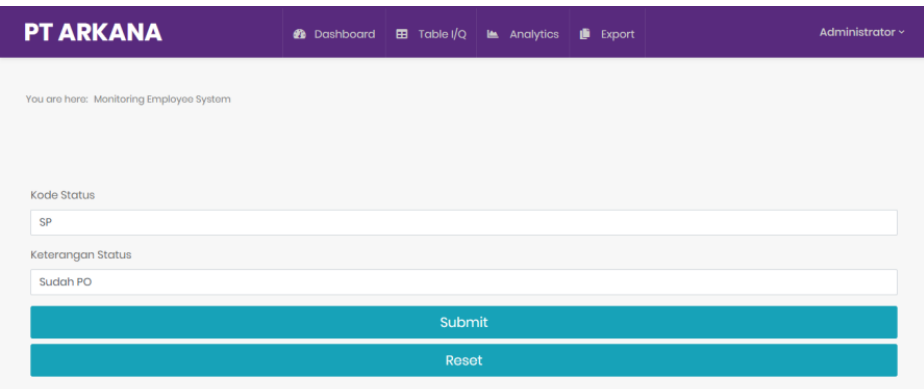

Sumber: Hasil Penelitian (2020)

\section{Gambar 5. Form Progress}

Gambar 6 merupakan tampilan quickview yang dapat menampilkan statistik dari proges penjualan software $O D O O$ yang dilakukan oleh karyawan dengan berdasarkan status Quote dan sstatus Puchase Order yang terjadi setiap satu bulan. Sehingga bagian HRD dapat memonitoring dan menilai kinerja dari masing-masing karyawan dalam menyelesaikan penjualan dan layanan implementasi software ODOO terhadap klien.

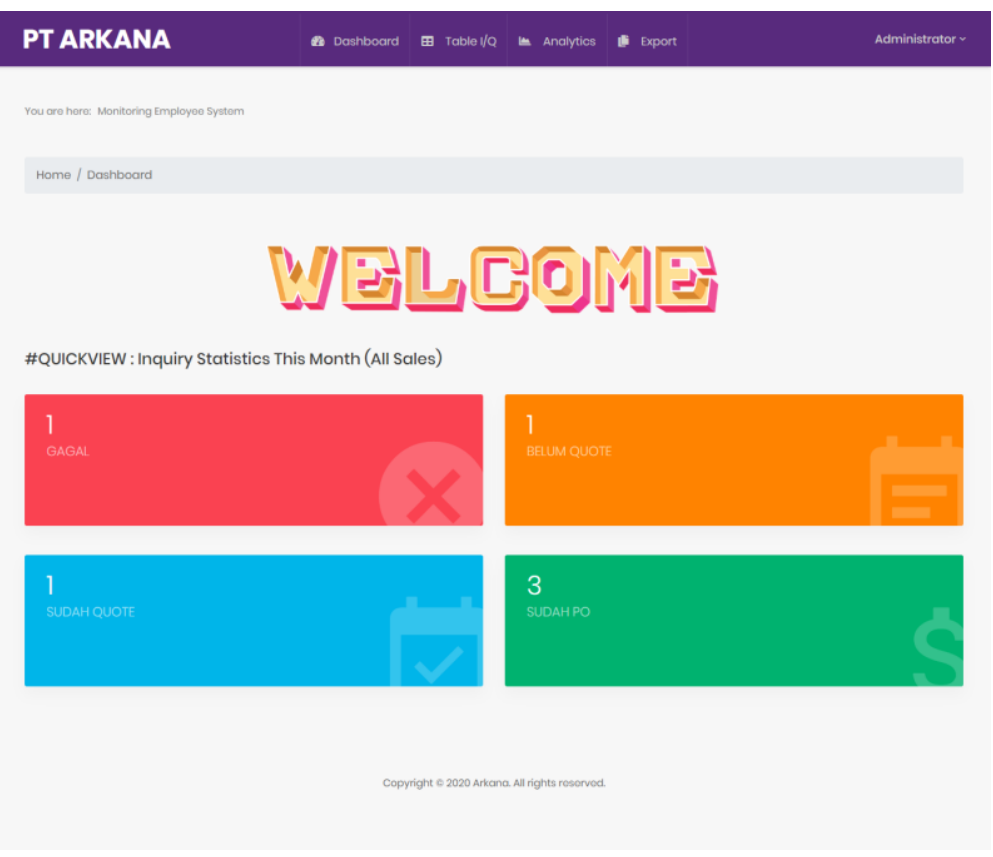

Sumber: Hasil Penelitian (2020)

Gambar 6. Form Menu Utama Menampilkan Statistik Kinerja

\section{Kesimpulan}

Setelah melakukan penelitian, maka dihasilkan sistem informasi yang sesuai dengan kebutuhan dari pihak PT Arkana Solusi Digital untuk menangani monitoring kinerja karyawan. Sehingga dengan diterapkannya sistem ini dapat membuat proses memonitoring kinerja 
karyawan menjadi mudah dapat dilakukan setiap saat, dapat membuat proses monitoring tidak memerlukan waktu yang lama karena dapat dilakukan dan secara real time sehingga proses monitoring menjadi efektif dan efisien, keakuratan dalam membuat laporan kinerja karena data yang di masukkan ke dalam sistem terekam secara historis kedalam database yang dapat disajikan sebagai laporan dalam tampilan yang memudahkan monitoring kinerja.

\section{Daftar Pustaka}

Budirahardjo. (2015). Panduan Praktis Penilaian Kinerja Karyawan. Raih Asa Sukses.

Dewi, M. A., \& Andriyani, R. (2017). Implementasi Scrum Model Development Pada Monitoring Inventory Control Cleaning Equipment dan Chemical PT. Explore Global Solution. Jurnal ULTIMA InfoSys, 8(2), 112-117. https://doi.org/10.31937/si.v8i2.669

Fattah, H. (2017). Kepuasan Kerja dan Kinerja Pegawai Elmatera. Penerbit Elmatera. https://books.google.co.id/books?id=w3pCDwAAQBAJ\&printsec=copyright\&hl=id\&source= gbs_pub_info_r\#v=onepage\&q\&f=false

Ikhsan, M. D. Al, Pradana, F., \& Bachtiar, F. A. (2019). Pengembangan Sistem Berbasis Web untuk Monitoring LEAD ( Studi Kasus Website Document Solution ). Jurnal Pengembangan Teknologi Informasi Dan IImu Komputer, 3(5), 4424-4433. https://jptiik.ub.ac.id/index.php/j-ptiik/article/view/5224

Larasati, S. (2018). Manajemen Sumber Daya Manusia. Deepublish. https://books.google.co.id/books/about/Manajemen_Sumber_Daya_Manusia.html?id=XRR kDwAAQBAJ\&redir_esc $=y$

Riniwati, H. (2016). Manajemen Sumberdaya Manusia Aktivitas Utama dan Pengembangan SDM. UB Press. https://opac.perpusnas.go.id/DetailOpac.aspx?id=1142613

Salsabila, S., Trisnadoli, A., \& Muslim, I. (2019). Rancang Bangun Sistem Informasi Monitoring Menggunakan Metode Agile dengan Dynamic System Development Model Guna Mendukung Gender Mainstreaming Strategy (Studi Kasus: Politeknik Caltex Riau). Jurnal TEKNIK, 4O(3), 195-202. https://doi.org/10.14710/teknik.v40i3.25704

Tyoso, J. S. P. (2016). Sistem Informasi Manajemen. Deepublish. https://books.google.co.id/books/about/Sistem_Informasi_Manajemen.html?id=0sKIDwAA QBAJ\&redir_esc $=\mathrm{y}$

Utomo, V. G., \& Putra, T. W. A. (2017). Sistem Informasi Evaluasi Kinerja Berbasis Web (Studi Kasus: STMIK PROVISI). 2nd Seminar Nasional IPTEK Terapan (SENIT) 2017, 2, 32-36. http://conference.poltektegal.ac.id/index.php/senit2017

Wahyuniardi, R., Afrianti, L. H., Nurjaman, S., \& Gusdya, W. (2015). Sistem Informasi Berbasis Web Untuk Monitoring dan Evaluasi Setra Industri Kecil di Jawa Barat. Jurnal IImiah Teknik Industri, 14(2), 174-186. https://journal.untar.ac.id/index.php/industri/article/viewFile/459/403 